\title{
Survival rates of patients with breast cancer in countries in the Eastern Mediterranean Region: a systematic review and meta-analysis
}

\author{
Khadije Maajani, ${ }^{1}$ Mahmoud Khodadost, ${ }^{2,3}$ Arash Fattahi ${ }^{4}$ and Aliyar Pirouzi ${ }^{5}$
}

${ }^{1}$ Department of Epidemiology and Biostatistics, School of Public Health, Tehran University of Medical Sciences, Tehran, Islamic Republic of Iran. ${ }^{2}$ Department of Epidemiology, School of Public Health, Shahid Beheshti University of Medical Sciences, Tehran, Islamic Republic of Iran (Correspondence to: Mahmoud Khodadost: mahmodkhodadost@yahoo.com). ${ }^{3}$ Department of Epidemiology, School of Public Health; ${ }^{4}$ Department of Neurosurgery, Iran University of Medical Sciences, Tehran, Islamic Republic of Iran. ${ }^{5}$ Cellular and Molecular Research Center, Gerash University of Medical Sciences, Gerash, Islamic Republic of Iran.

\begin{abstract}
Background: Breast cancer is the fourth leading cause of death and disability in the Eastern Mediterranean Region (EMR); although the incidence is lower than in the developed regions, there has been an increasing trend in recent decades.

Aims: Our aim was to calculate the pooled survival rate of patients with breast cancer in the EMR.

Methods: We searched electronic databases from 1946 to 19 January 2018, without language restrictions. We used a random effect model to estimate pooled 1-, 3-, 5- and 10-year survival rates for patients with breast cancer. Chi-squared and $I^{2}$ index were used to assess between-study heterogeneity. Subgroup analysis and meta-regression were used to investigate the potential source of heterogeneity.

Results: We found 80 articles eligible for inclusion in our review. The pooled 1-, 3-, 5- and 10-year survival rates in women with breast cancer in the EMR were $0.95,0.80,0.71$, and 0.56 , respectively. The $I^{2}$ index indicated considerable between-study heterogeneity (all $\mathrm{I}^{2}>50 \%$ ). The 5-year survival rate in the male subgroup was 0.63 . The 5-year survival rate of women with breast cancer in age groups $\leq 39,40-64$, and $65+$ years were $0.74,0.76$ and 0.58 , respectively. There was a statistically significant association between the Human Development Index $(\beta=9, P=0.01)$ and decade of study ( $\beta=8.2$, $P=0.04$ ) and 5-year survival rate.

Conclusions: The survival rate of women with breast cancer in those countries in the EMR which have better health care systems improved in the past decade; women aged 40-64 years had the best survival rate.

Keywords: review, breast cancer, survival rate, Eastern Mediterranean Region, meta-analysis

Citation: Maajani K; Khodadost M; Fattahi A; Pirouzi A. Survival rates of patients with breast cancer in countries in the Eastern Mediterranean Region: a systematic review and meta-analysis. East Mediterr Health J. 2020;26(2):219-232 https://doi.org/10.26719/2020.26.2.219

Received: 05/03/2018; accepted: 23/08/2018

Copyright (c) World Health Organization (WHO) 2020. Open Access. Some rights reserved. This work is available under the CC BY-NC-SA 3.o IGO license (https://creativecommons.org/licenses/by-nc-sa/3.o/igo).
\end{abstract}

\section{Introduction}

Breast cancer is among the 4 most common cancers in the world (1). It is the leading cause of death among women in developed countries and the second commonest cause of death in developing countries $(2,3)$. In 2015 , among women, an estimated 321840 new cases of invasive breast cancer were projected (4). In the WHO Eastern Mediterranean Region (EMR), breast cancer is the fourth leading cause of death and disability $(1,3,5)$ and the number one cancer in 16 of the 22 countries in the Region (6). The age-standardized incidence of breast cancer in this Region is $12-50$ per 100000 in women, with the lowest incidence in the Islamic Republic of Iran and Pakistan (3). Although the incidence in this Region is lower than in the developed regions, there has been an increasing trend in recent decades $(10,11)$.

The EMR comprises 22 countries with varied ethnicity and cultures (7). The women in this Region generally have poor knowledge about screening methods for breast cancer (6). In Bahrain, Egypt, the Islamic Republic of Iran, Jordan, Kuwait, Lebanon, Oman, Saudi Arabia and Tunisia, breast cancer is usually diagnosed in women under age 50 years, i.e. younger than in other parts of the world (6).
An important factor that affects survival is the disease stage at diagnosis, ranging from $\geq 80 \%$ in North America, Sweden and Japan to around $60 \%$ in middle-income countries and $<40 \%$ in low-income countries (7). In the EMR, patients with breast cancer are usually diagnosed for the first time at stages 2 and $3(3,6)$. The difference in survival between developed and developing countries may be due to delays in diagnosis.

The aim of this study is to determine survival of patients with breast cancer by age, stage of disease and overall in the EMR by systematic review and metaanalysis.

\section{Methods}

\section{Reporting guidelines}

The Preferred Reporting Items for Systematic Reviews and Meta-Analyses (PRISMA) guidelines was used to carry out and report this systematic review and meta-analysis (8).

\section{Study selection}

We used the following inclusion and exclusion criteria to select relevant articles in this meta-analysis. All 
observational cohort studies that reported the survival rate of women with primary invasive breast cancer in different study populations in the EMR were included with no restriction for language, age, ethnicity or religion. We excluded articles that reported the survival rate after relapse. Letters to the editor, review articles and meeting abstracts were also excluded. Where we found several publications from the same study population, we choose the most recent one to include in our study. To select the relevant articles from the search results, 2 reviewers (KM and MK) independently screened the studies by title, abstract and full text; in the case of disagreement between the 2 reviewers, they entered into discussion and if required a 3 rd investigator became involved to resolve the question.

\section{Search strategy}

A systematic search was carried out by 2 reviewers (KM and MK) independently in several electronic databases such as Medline/PubMed, Web of Science, Scopus, and Google Scholar covering material published from 1946 to 19 January 2018. The search strategy was made using the $\mathrm{MeSH}$ subject headings and free text words like ("breast neoplasms" [MeSH] or "breast cancer" or "breast carcinoma" or "breast tumour" or "breast malignant") AND ("survival" or "survival analysis" or "survival rate" or "life table" or "Kaplan Meier " or "proportional hazard model" or "hazard ratio" or "Cox model" or "Cox regression") AND ("cohort" or "prospective" or "retrospective" or "follow-up" or "longitude"). To identify additional relevant studies, we reviewed the reference lists of all included studies. To manage and screen eligible searched studies, we used EndNote $\mathrm{X} 7$ citation manager.

\section{Quality assessment}

To assess the quality of each eligible study and risk of bias we used the Strengthening the Reporting of Observational Studies in Epidemiology (STROBE) checklist (9). We used several items from this checklist: define the source of participant selection, explain the eligibility criteria, explain about follow-up and how to address the missing data, clearly define how to measure the outcome and explain about the size of the study. The studies were classified into 3 groups based on this checklist. If the studies attained more than $80 \%$ of the total score, they were classified as high quality, $60-79 \%$ of total score as intermediate quality and $30-59 \%$ of total score as low quality. Two authors (KM and $\mathrm{MK}$ ) independently investigated the quality of each study. The agreements between reviewers were assessed by weighted Kappa (86\%).

\section{Data extraction}

For each eligible study, the variables were extracted on a prespecified sheet in Microsoft Excel 2010 as follows: first author name, year of publication, period of study, country of origin, source of data, study design, median follow-up time, sample size, mean age, gender frequency, type of survival, 1-, 3-, 5- and 10-year survival rates and $95 \%$ confidence interval (CI). Data extraction was performed independently by 2 reviewers (KM and MK).
Disagreement was resolved by discussion between the 2 reviewers and if required, a senior investigator solved the discrepancies.

\section{Statistical analysis}

We investigated statistical heterogeneity using the $\mathrm{Q}$ test at the $5 \%$ significance level $(P<0.05)$ and $I^{2}$ index. According to the significant between-study heterogeneity $(P<0.05)$, random effect models was used. Because some studies did not report the standard error and 95\% confidence interval (CI), we also used binomial distribution to estimate the variance and 95\% CIl of all included studies.

To estimate the pooled survival rate we used metan and metaprop commands. The metaprop command was specific to binomial data and for proportions near boundaries (in this instance, $100 \%$ at 1-year survival or $0 \%$ at stage IV), which allows computation of exact binomial and score test-based CIs by allowing FreemanTukey double arcsine transformation to stabilize the variances (10)

To investigate the potential source of heterogeneity we used subgroup analyses based on sex, age and stage at diagnosis, ethnicity, Human Development Index (HDI) and decade of study. We also conducted subgroup analysis based on the level of development, income and health outcome, so all 22 countries were categorized into 3 subgroups. Group 1 includes countries that are developed in the past decade, Group 2 includes middle-income countries and Group 3 includes countries less developed than the others in the Region, e.g. Afghanistan (11,12).

Meta-regression was used based on decade of study, HDI, ethnicity, and sample size to find the source of heterogeneity. Publication bias was not assessed, because the probability of survival rate as a proportion is always a positive number and if we see asymmetry in a funnel plot, it is not due to publication bias.

We used EndNote $\mathrm{X}_{7}$ to manage the records and review the results of the systematic search and Microsoft Excel 2010 to prepare the data extraction sheet. We used Stata 11 to perform statistical analysis.

\section{Results}

\section{Study characteristics}

The initial search identified 1292 articles up to 19th January 2018. After removing duplicates and screening by title, abstract and full text, 80 eligible articles remained in our systematic review and meta-analysis. A flow diagram of selection process according to the PRISMA flowchart is shown in Figure 1.

The characteristics of these 80 studies are summarized in Table 1 . These articles come from 12 countries in the EMR. Half of the studies were conducted in the Islamic Republic of Iran ( $n=40) ; 12$ articles were exclusively conducted on men and 68 on women. Also, 6 studies were exclusively conducted on women under 39 years. The total sample size from the 80 studies was 42328 , of whom 41603 (98.2\%) were female. 


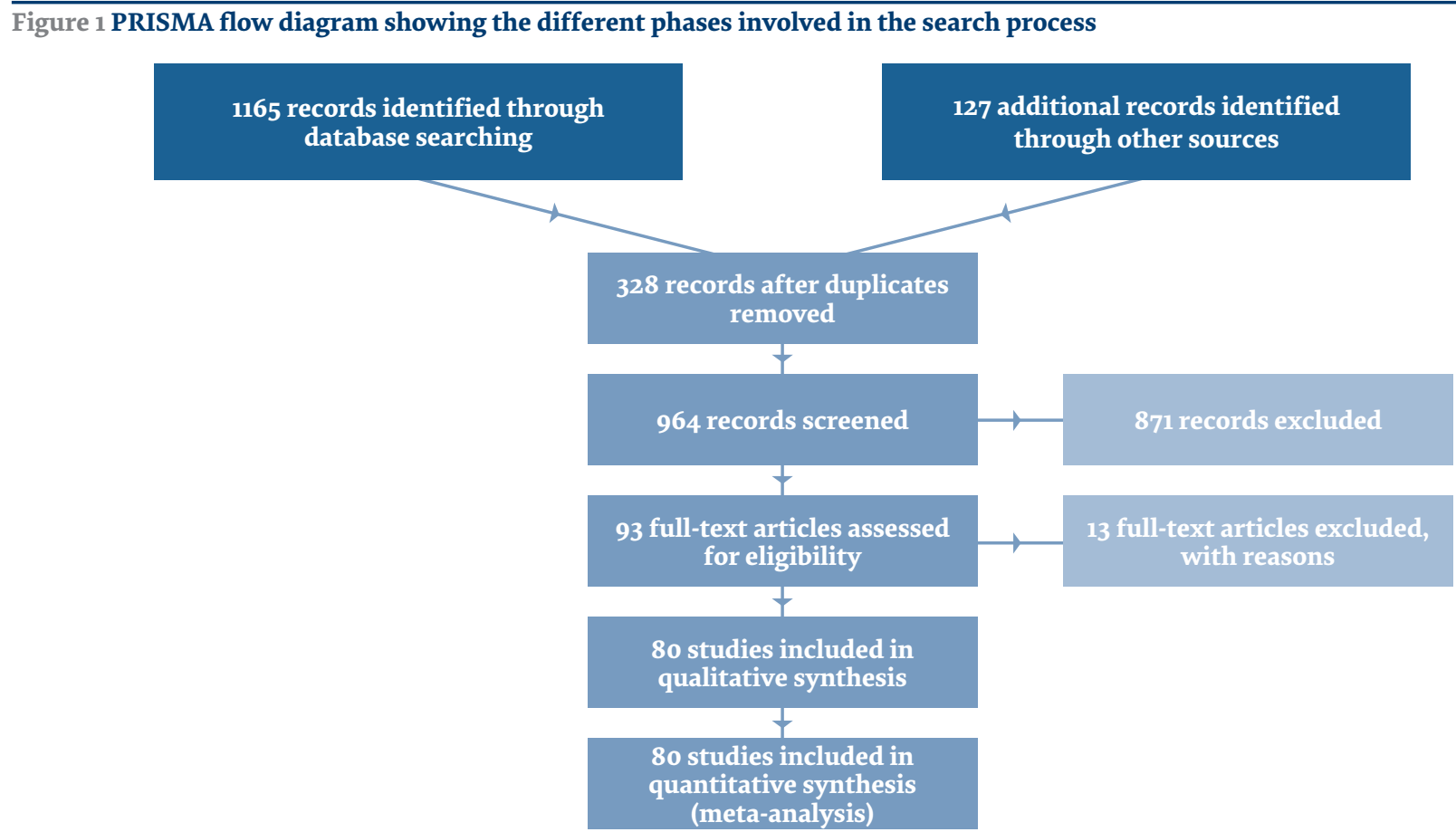

\section{Pooled survival rate}

The pooled 1-, 3-, 5- and 10-year survival rate of women with breast cancer in the EMR were 0.95 (95\% CI: 0.930.96 ), 0.80 (95\% CI: $0.76-0.84$ ), 0.71 (95\% CI: $0.68-0.73$ ) and 0.56 (95\% CI: 0.48-0.63), respectively. We saw considerable heterogeneity in 1-year $\left(P<0.001, I^{2}=92.83\right)$, 3-year $\left(P<0.001, I^{2}=96.38\right)$, 5-year $\left(P<0.001, I^{2}=92.24\right)$ and 10year $\left(P<0.001, I^{2}=97.33\right)$ survival rates among women with breast cancer.

\section{Subgroup analysis}

The results of the subgroup analyses are shown in Table 2. The pooled 5-year survival rate in women was $0.71(95 \%$ CI: 0.68-0.73) and in men was 0.63 (95\% CI: 0.59-0.67). In the age subgroups, the 5 -year survival rates for women with breast cancer aged $<39,40-64$, and $65+$ years were 0.74 (95\% CI: $0.68-0.80), 0.76$ (95\% CI: $0.66-0.85$ ) and 0.58 (95\% CI: 0.46-0.69) respectively.

\section{Meta-regression}

To determine any potential source of bias, we covered the variables sample size, HDI, decade of study and ethnicity as independent variables and survival rate as a dependent variable in meta-regression. In the univariable model, there was a statistically significant association between HDI $(\beta=9.0, P=0.012)$ and decade of study $(\beta=8.2, P=$ 0.048 ) and 5-year survival rate. The 5-year survival rate increased with the decade of study (Table 3 ).

\section{Discussion}

The aim of this study was to estimate the survival rate of women with breast cancer in the EMR. From the meta-analysis, the 1-, 3-, 5- and 10-year survival rates were 0.95 (95\% CI: 0.93-0.96), 0.80 (95\% CI: 0.76-0.84), 0.71 (95\% CI: $0.68-0.73)$ and $0.56(95 \%$ CI, $0.48-0.63)$ respectively.
The 1-year survival rate in a 2009 study from England (96\%) and Australia (98.1\%) is consistent with the results of our study (13). The 1- and 3-year survival rates were reported in a 2014 study from China as $76.0-83.1 \%$ and $51.5-74.1 \%$, respectively (14). In a 2004 study conducted in India, the 1 - and 3-year survival rates were $76 \%$ and $51.5 \%$ respectively (15). Our findings indicate that the 1-year survival rates in the EMR are similar to those in some developed countries and better than in some developing countries such as India.

In a 2015-2016 report from the American Cancer Society the $5^{-}$and 10-year relative survival rates were $89 \%$ and $83 \%$ respectively (16). In a study conducted in European countries in 2013, the 5-year relative survival rate was $69-84 \%(17)$. On the other hand, in a 2010 study conducted in developing countries, the 5 -year relative survival rate varied from $52 \%$ in India to $82 \%$ in China (18). Comparing with our findings, the 5- and 10-year survival rates in the EMR were lower than in the highincome countries and similar to those in the developing countries.

An important factor that may account for the differences in survival rates among women with breast cancer in the EMR might be the (lack of) improvement of the health systems in some countries; a poorly developed health system can result in late diagnosis and improper treatment of patients with advanced cancer. Additionally, the lack of a population-based cancer registry in some countries may result in insufficient surveillance and a failure in monitoring any control programme. False beliefs and low levels of knowledge and awareness in some populations in the Region are other likely reasons for these differences $(1,5,19)$. Survival data in the EMR depend on good registries. Some countries do have data, some have data but the quality is not known, and some 


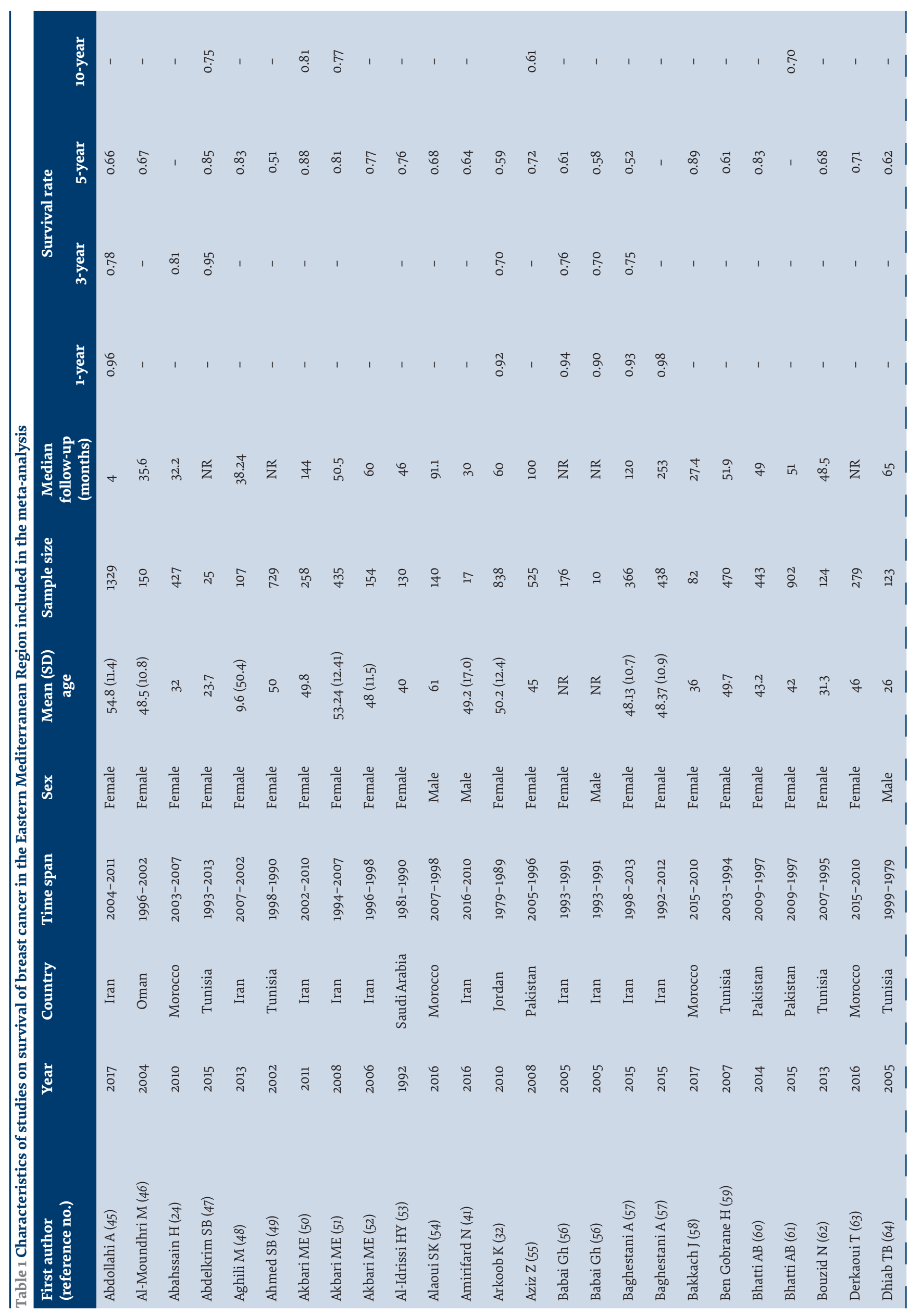




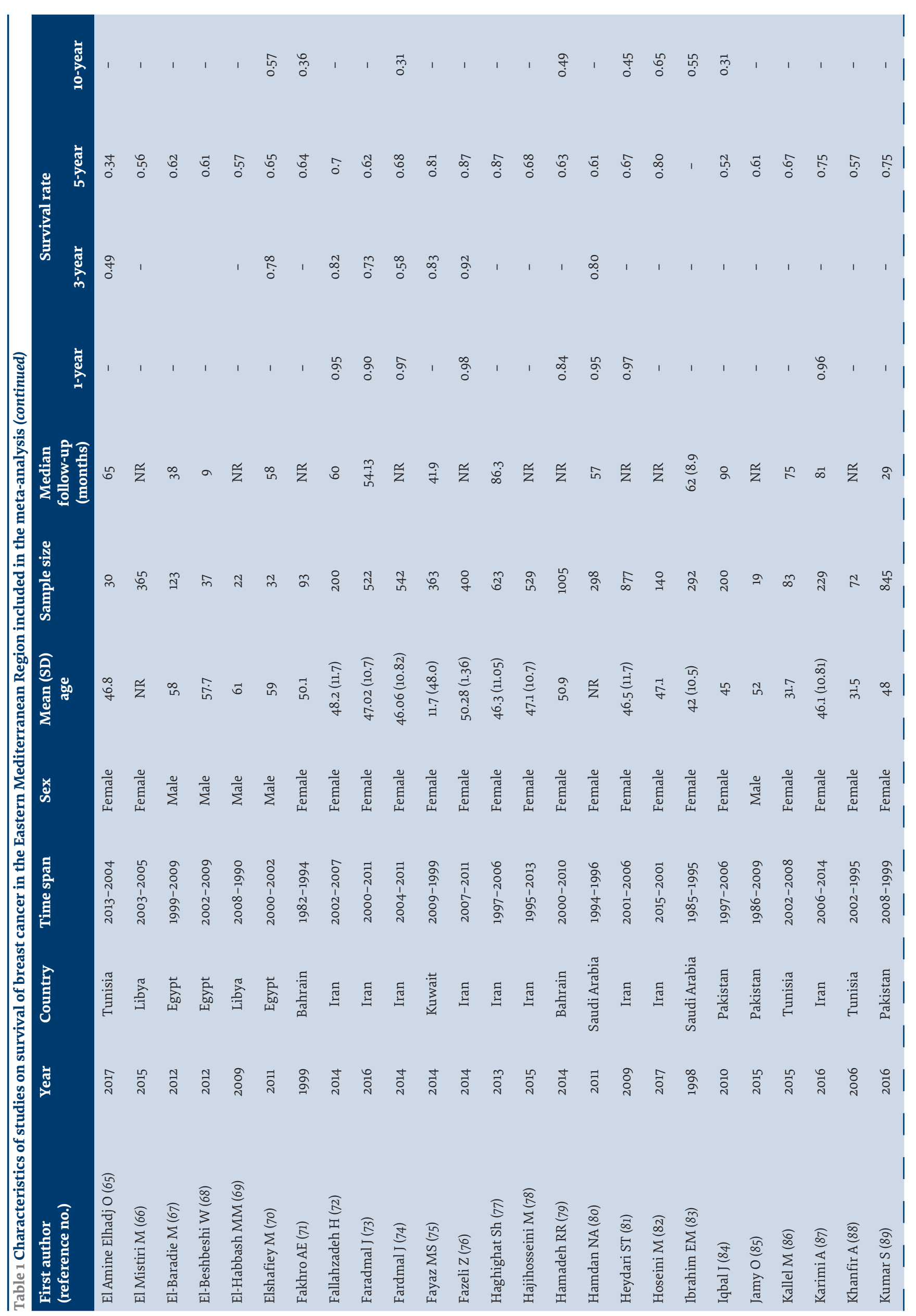




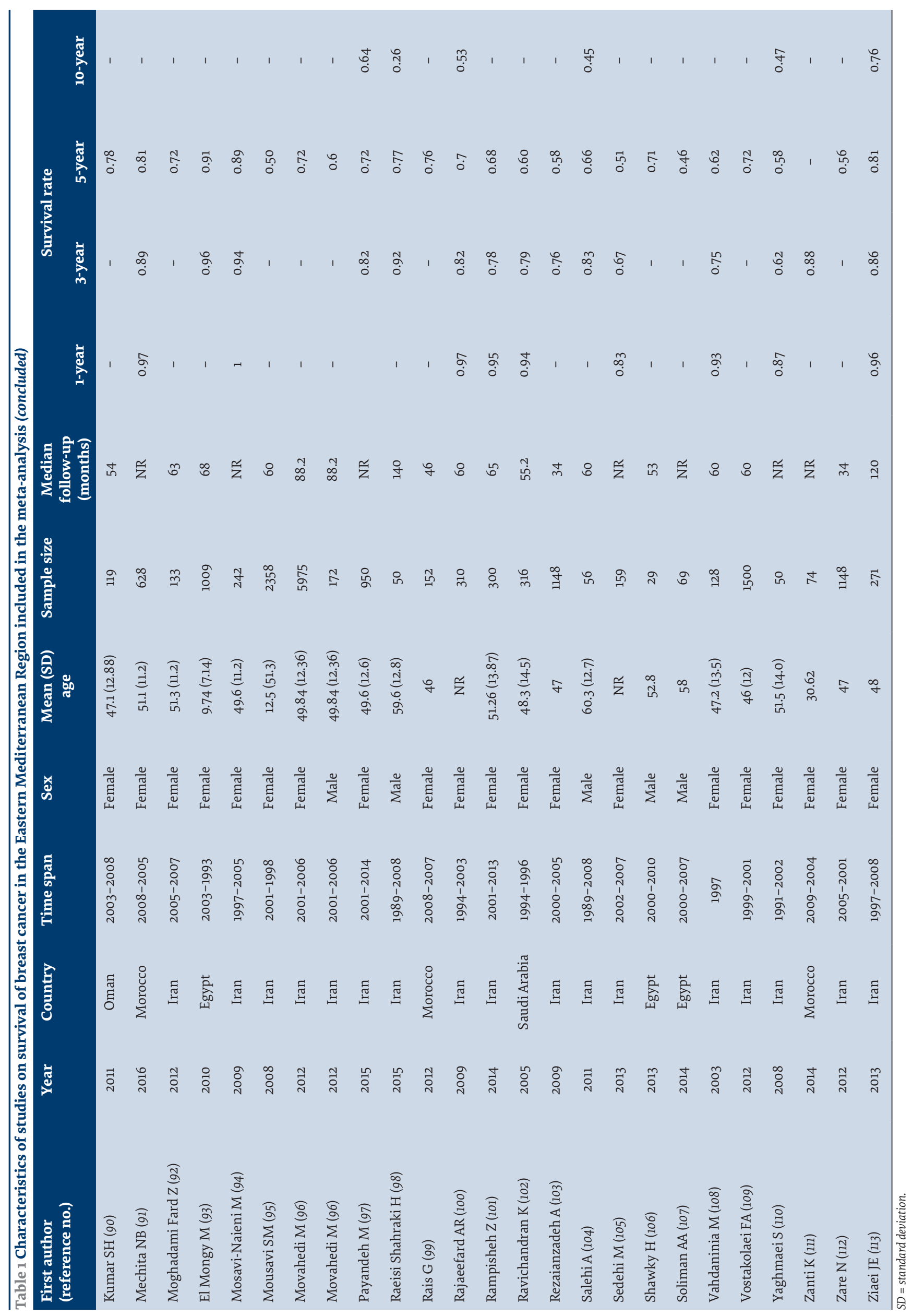




\begin{tabular}{|c|c|c|c|c|}
\hline \multirow[t]{2}{*}{ Category/ subgroup } & \multicolumn{4}{|c|}{ Survival rate ( $95 \%$ confidence interval) } \\
\hline & 1-year & 3-year & 5-year & 10-year \\
\hline \multicolumn{5}{|l|}{ Sex } \\
\hline Female & $0.95(0.93-0.96)$ & $0.80(0.76-0.84)$ & $0.71(0.68-0.73)$ & $0.56(0.48-0.63)$ \\
\hline Male & - & $0.84(0.75-0.92)$ & $0.63(0.59-0.67)$ & $0.41(0.25-0.59)$ \\
\hline \multicolumn{5}{|l|}{ Decade of study } \\
\hline 1990-1999 & $0.93(0.92-0.94)$ & $0.76(0.71-0.80)$ & $0.63(0.58-0.68)$ & $0.50(0.45-0.55)$ \\
\hline $2000-2009$ & $0.96(0.93-0.98)$ & $0.84(0.77-0.89)$ & $0.72(0.68-0.75)$ & $0.58(0.47-0.69)$ \\
\hline $2010-2018$ & $0.95(0.91-0.97)$ & $0.77(0.70-0.84)$ & $0.72(0.67-0.76)$ & $0.56(0.42-0.69)$ \\
\hline \multicolumn{5}{|l|}{ Stage at diagnosis } \\
\hline I & - & - & $0.90(0.81-0.97)$ & - \\
\hline II & - & - & $0.77(0.71-0.83)$ & - \\
\hline III & - & - & $0.57(0.49-0.64)$ & - \\
\hline IV & - & - & $0.37(0.19-0.57)$ & - \\
\hline \multicolumn{5}{|l|}{ Age (years) } \\
\hline Under 39 & - & - & $0.74(0.68-0.80)$ & - \\
\hline $40-64$ & - & - & $0.76(0.66-0.85)$ & - \\
\hline $65^{+}$ & - & - & $0.58(0.46-0.69)$ & - \\
\hline \multicolumn{5}{|l|}{ Ethnicity } \\
\hline Arab & $0.93(0.88-0.97)$ & $0.83(0.75-0.90)$ & $0.69(0.62-0.75)$ & $0.51(0.42-0.60)$ \\
\hline Other & $0.95(0.94-0.97)$ & $0.78(0.74-0.82)$ & $0.71(0.69-0.74)$ & $0.57(0.47-0.66)$ \\
\hline \multicolumn{5}{|c|}{ Human Development Index } \\
\hline Very high & $0.91(0.83-0.97)$ & $0.81(0.78-0.83)$ & $0.68(0.60-0.75)$ & $0.48(0.40-0.56)$ \\
\hline High & $0.95(0.94-0.97)$ & $0.78(0.74-0.82)$ & $0.69(0.66-0.72)$ & $0.59(0.48-0.71)$ \\
\hline Medium & $0.97(0.95-0.98)$ & $0.89(0.80-0.96)$ & $0.82(0.73-0.90)$ & - \\
\hline Low & - & - & $0.73(0.64-0.80)$ & $0.54(0.35-0.73)$ \\
\hline \multicolumn{5}{|l|}{ EMR country grouping ${ }^{a}$} \\
\hline Group 1 & $0.91(0.83-0.97)$ & $0.80(0.77-0.82)$ & $0.70(0.64-0.75)$ & $0.48(0.40-0.56)$ \\
\hline Group 2 & $0.96(0.94-0.97)$ & $0.78(0.73-0.83)$ & $0.68(0.66-0.71)$ & $0.54(0.44-0.64)$ \\
\hline Group 3 & - & - & $0.67(0.57-0.77)$ & $0.58(0.43-0.72)$ \\
\hline
\end{tabular}

${ }^{a}$ All 22 countries in the Region are categorized into 3 groups based on level of development and income. Group 1: Bahrain, Kuwait, Oman, Qatar, Saudi Arabia and United Arab Emirates. Group 2: Egypt, Islamic Republic of Iran, Iraq, Jordan, Lebanon, Libya, Morocco, occupied Palestinian territory, Syrian Arab Republic and Tunisia. Group 3: Afghanistan, Djibouti, Pakistan, Somalia, Sudan and Yemen.

low-income countries have no published papers on survival. Consequently, our results actually represent the pooled survival rates of patients with breast cancer in those countries in the EMR which have better health care systems.

The results of the subgroup analysis indicated that women with breast cancer who were younger than 39 years may have the lowest survival rate. The highest survival rate was in those aged 40-64 years. In a study from Sweden in 2009 the 5 -year survival rates in women aged 20-34, 35-39, 40-49 and 50-69 years were $74.7 \%$, $83.8 \%, 88.3 \%$ and $87.8 \%$ respectively (20), which was consistent with the result of our study. Also, the results from a 2016 study in Canada (21) and a 2017 Iranian study (22) confirm our findings. Some research has reported that the age of onset of breast cancer in women of the EMR and also Asian women is lower than their European and American counterpart (23). Breast cancer is a rare disease in young women, however the clinical and pathological outcomes are more aggressive than in older patients $(20,21)$. Several studies have indicated that age is a significant predictor of survival in patients with breast cancer. A number of factors may affect the survival rates in women with breast cancer, e.g. late presentation and diagnosis at an advanced stage, more aggressive tumours in young women $(20,24,25)$, and hormonal, immunological and biological differences between younger and older women $(26,27)$. This hormonal difference in young women may result in more rapidly growing tumour and thus reduced survival rates $(26,28)$. Also younger women with breast cancer may have more recurrence than other age groups (26).

One of the most important prognostic factors for survival of patients with breast cancer is stage at 


\begin{tabular}{|c|c|c|c|c|c|c|c|}
\hline \multirow[t]{2}{*}{ Survival } & \multirow[t]{2}{*}{ Variable } & \multicolumn{3}{|c|}{ Univariable model } & \multicolumn{3}{|c|}{ Multivariable model } \\
\hline & & $\boldsymbol{\beta}$ & SE & P-value & $\boldsymbol{\beta}$ & SE & P-value \\
\hline \multirow[t]{4}{*}{ 1-year } & Sample size & 2.7 & 2.4 & 0.281 & -0.7 & 2.3 & 0.761 \\
\hline & HDI & 3.1 & 4.8 & 0.525 & 11.8 & 5.2 & 0.032 \\
\hline & Decade of study & 3.1 & 3.0 & 0.763 & -5.9 & 3.2 & 0.091 \\
\hline & Ethnicity & 4.4 & 2.2 & 0.068 & 9.7 & 3.1 & 0.007 \\
\hline \multirow[t]{4}{*}{ 3-year } & Sample size & -1.9 & 4.6 & 0.612 & -1.3 & 4.3 & 0.752 \\
\hline & HDI & 11.8 & 4.8 & 0.028 & 11.0 & 7.5 & 0.134 \\
\hline & Decade of study & 4.0 & 5.0 & 0.482 & 1.5 & 6.0 & 0.823 \\
\hline & Ethnicity & -4.2 & 4.1 & 0.329 & -0.6 & 5.9 & 0.914 \\
\hline \multirow[t]{4}{*}{ 5-year } & Sample size & 3.6 & 3.1 & 0.234 & 3.0 & 2.9 & 0.325 \\
\hline & HDI & 9.0 & 3.6 & 0.012 & 8.1 & 3.7 & 0.036 \\
\hline & Decade of study & 8.2 & 3.9 & 0.048 & 5.4 & 4.1 & 0.179 \\
\hline & Ethnicity & 2.9 & 3.0 & 0.397 & 2.2 & 9.9 & 0.425 \\
\hline \multirow[t]{4}{*}{ 10-year } & Sample size & -2.7 & 9.2 & 0.752 & -0.6 & 11.0 & 0.981 \\
\hline & HDI & -1.0 & 10.3 & 0.952 & -3.0 & 11.0 & 0.834 \\
\hline & Decade of study & 10.5 & 12.1 & 0.443 & 11.0 & 20.0 & 0.516 \\
\hline & Ethnicity & 5.5 & 9.6 & 0.526 & -0.3 & 37.7 & 0.327 \\
\hline
\end{tabular}

SE $=$ standard error

HDI = Human Development Index

diagnosis. The result of our study indicated that the 5 -year survival rate of women with breast cancer in the EMR ranged from $90 \%$ for stage I to $37 \%$ for stage IV. In a 2016 report from the American Cancer Society the 5-year relative survival rate was between $99 \%$ at the local stage and $26 \%$ at the distant stage (16), similar to our findings. Also, a study from India in 2004 reported that the 5-year survival rate was from $69.7 \%$ at the local stage to $4 \%$ at the distant metastasised stage (15), which was much lower than our finding in the EMR. In developing region like the EMR, patients with breast cancer are usually diagnosed at an advanced stage due to the limited health care facilities, lack of awareness, and social barriers and cultural beliefs that can result in reduced survival (2).

Our findings indicated that the survival rate for women of all ages with breast cancer was better in the most recent decade. The 5-year survival rate in women in the EMR increased from 63\% in 1990-1999 to $72 \%$ in 2010-2018. The result of studies conducted in Canada (29) and in England (13) confirm our findings. This progress may be due to the screening programmes and cancer prevention and control strategies in the countries of the Region (1,30).

The survival rate of women with breast cancer in the Arab populations was lower than in the non-Arab populations in this Region. In a 2016 meta-analysis conducted in the Islamic Republic of Iran, the pooled 1-, $3-, 5-$ and 10-year survival rates in women were 95\%, 80\%, $69 \%$ and $55 \%$ respectively (31) and in a study from Jordan in 2010 the 1-, 3- and 5-year survival rates were $91 \%, 70 \%$ and $59 \%$ respectively (32), confirming the result of our study. The results of some studies indicate that Arab women with breast cancer may have a worse prognosis than other populations $(33,34)$. The reasons for this may be the young age of women at presentation and also late diagnosis (34). Also some studies noted that the proportion of negative estrogen and progesterone receptors in Arab women with breast cancer was high, which can lead to poor survival $(33,35,36)$.

In our meta-analysis we found that the 5-year survival rate in women was better than in men. Several studies indicate that sex is not an independent significant predictor for breast cancer survival (37-39) and the differences in survival may be due to the similarity between breast cancer in men and postmenopausal breast cancer in women $(37,40)$. Some studies note that male breast cancer was diagnosed approximately 5-10 years later than in women $(41,42)$. Also because of the general dearth of breast cancer screening programmes foe males, they are usually diagnosed at a later stage than women $(42,43)$. In some studies, the risk of local and regional recurrence in male breast cancer has been higher than women $(42,44)$.

We found that the 5-year survival rate in the very high HDI subgroup was much lower than in the low HDI subgroup. In the medium and low HDI subgroups we have countries such as Afghanistan, Djibouti, Iraq, Palestine, Sudan, Somalia and Syrian Arab Republic but we did not have any relevant study about the survival rate for breast cancer in these countries, so the pooled survival rate in these subgroups are concluded from only a few countries, and therefore we should expect this bias.

One of the main limitations of this review is that, from the 22 countries in the EMR, we only have studies from 
12 countries. So the estimate of the pooled survival rate in this Region can be representative of survival of only those countries which have a better health care system.

\section{Conclusion}

Although the search targeted all EMR countries, our results represented countries in the EMR with better health care systems, because the countries with no published papers on survival are mainly low income countries. The survival rate of women in the countries in the EMR which have better health care systems is between the rates in the developed and developing regions. We found that, as in other parts of the world, survival rate have improved in recent decades. Although the survival rate will further improve owing to the implementation of screening and control programmes, we need more informative programmes to improve the awareness among females about the early sign and symptoms of this disease.

Funding: None.

Competing interests: None declared.

\section{Taux de survie des patients atteints de cancer du sein dans les pays de la Région de la Méditerranée orientale : analyse systématique et méta-analyse}

\section{Résumé}

Contexte : Le cancer du sein est la quatrième cause de mortalité et d'incapacité dans la Région de la Méditerranée orientale ; bien que son incidence soit moindre que dans les régions développées, la tendance a été à la hausse au cours des dernières décennies.

Objectif : La présente étude avait pour objectif de calculer le taux de survie combiné des patients atteints de cancer du sein dans la Région de la Méditerranée orientale.

Méthodes : Nous avons effectué des recherches dans les bases de données électroniques de 1946 au 19 janvier 2018 , sans restriction de langue. Un modèle à effet aléatoire a été utilisé pour estimer les taux de survie combinés à 1, 3, 5 et 10 ans pour les patients atteints de cancer du sein. Le test $\chi^{2}$ et l'indice $I^{2}$ ont été utilisés pour évaluer l'hétérogénéité entre les études. Une analyse de sous-groupe et une méta-régression ont été utilisées pour étudier la source potentielle d'hétérogénéité.

Résultats : Nous avons trouvé 80 articles éligibles pour être inclus dans notre analyse. Les taux de survie combinés à 1, 3 , 5 et 10 ans chez les femmes atteintes de cancer du sein dans la Région de la Méditerranée orientale étaient respectivement de 0,$95 ; 0,80 ; 0,71$ et 0,56 . L'indice $I^{2}$ a mis en évidence une hétérogénéité considérable entre les études (toutes ayant rapporté un indice $I^{2}$ supérieur à $50 \%$ ). Le taux de survie à 5 ans dans le sous-groupe masculin était de 0,63. Le taux de survie à 5 ans chez les femmes atteintes de cancer du sein dans les tranches d'âge inférieur ou égal à 39, compris entre 40 et 64 ans et des plus de 65 ans étaient respectivement de 0,$74 ; 0,76$ et 0,58 . Une corrélation statistiquement significative a été relevée entre l'indice de développement humain $(\beta=9, p=0,01)$, la décennie de l'étude $(\beta=8,2, p=0,04)$ et le taux de survie à 5 ans.

Conclusions : Le taux de survie des femmes atteintes de cancer du sein dans les pays de la Région de la Méditerranée orientale qui ont les meilleurs systèmes de santé s'est amélioré au cours de la dernière décennie. Les femmes dont l'âge était compris entre 40 et 64 ans avaient le meilleur taux de survie.

$$
\begin{aligned}
& \text { معدلات نجاة المرضى المصابين بسرطان الثدي في إقليم شرق المتوسط: استعر اض منهجي وتحليل تلوي } \\
& \text { خديجة ماجاني، محمود خودادوست، آرش فتاحي، عليار بيروزي } \\
& \text { الخالاصة }
\end{aligned}
$$

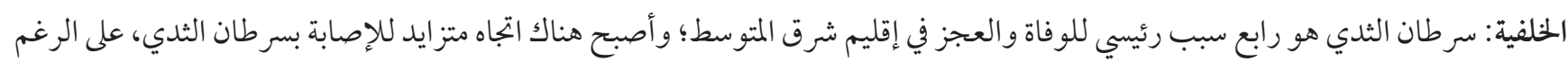

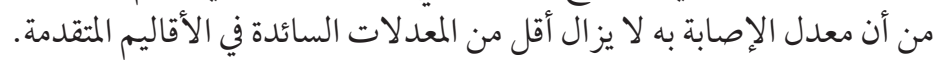

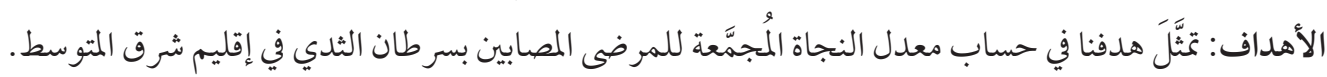

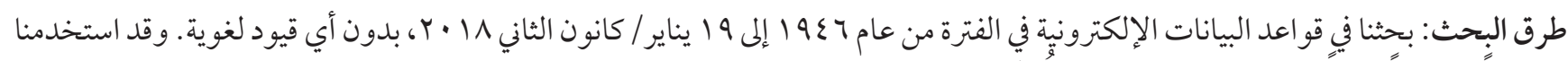

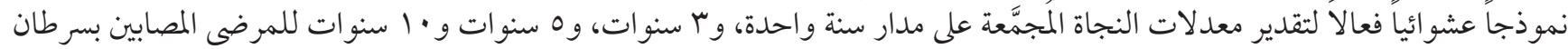

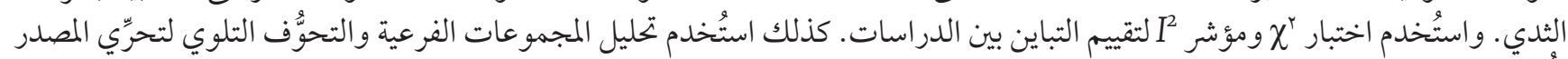

$$
\begin{aligned}
& \text { المحتمل للتباين. }
\end{aligned}
$$

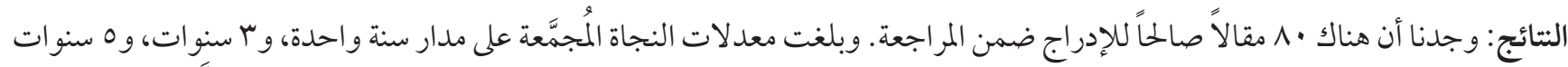

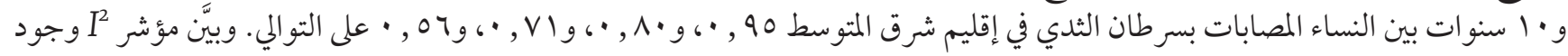




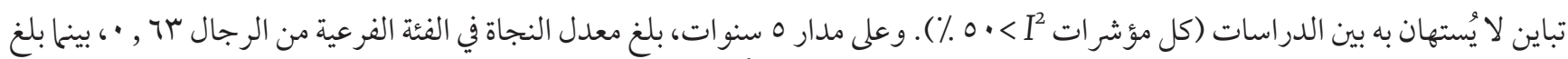

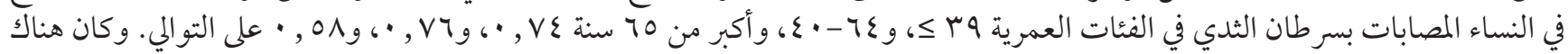

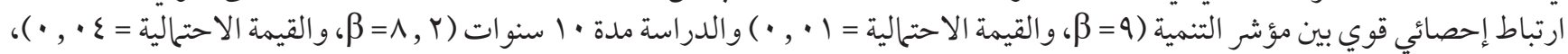

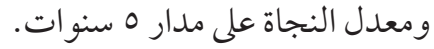

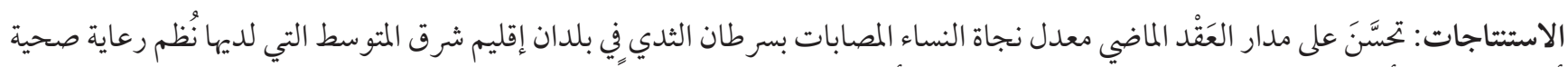
أفضل، وكانت أفضل معدلات علات النجاة بين النساء التي تتراوح أعمارهن بين عاء عـ - • ع عاماً.

\section{References}

1. Organization WH. Strategy for cancer prevention and control in the Eastern Mediterranean Region 2009-2013. 2010.

2. Garcia M, Jemal A, Ward E, Center M, Hao Y, Siegel R, et al. Global cancer facts \& figures, 3rd ed. Atlanta: American Cancer Society; 2015.

3. Khatib OM, Modjtabai A. Guidelines for the early detection and screening of breast cancer. Cairo: World Health Organization, Regional Office for the Eastern Mediterranean; 2006.

4. Breast cancer facts \& figures 2015-2016. Atlanta: American Cancer Society; 2015.

5. Omar S, Alieldin N, Khatib O. Cancer magnitude, challenges and control in the Eastern Mediterranean Region. East Mediterr Health J. 2007 Nov-Dec;13(6):1486-96. PMID:18341198

6. Namiranian N, Moradi-Lakeh M, Razavi-Ratki SK, Doayie M, Nojomi M. Risk factors of breast cancer in the Eastern Mediterranean Region: a systematic review and meta-analysis. Asian Pac J Cancer Prev. 2014;15(21):9535-41. doi:10.7314/apjcp.2014.15.21.9535

7. Sarvi F, Nadali A, Khodadost M, Moghaddam MK, Sadeghifar M. Application of Poisson Hidden Markov model to predict number of PM2. 5 exceedance days in Tehran during 2016-2017. Avicenna J Environ Health Engineer. 2017 Jun;4(1).

8. Moher D, Shamseer L, Clarke M, Ghersi D, Liberati A, Petticrew M, et al. Preferred reporting items for systematic review and meta-analysis protocols (PRISMA-P) 2015 statement. Syst Rev. 2015 Jan 1;4:1. doi:10.1186/2046-4053-4-1.

9. Von Elm E, Altman DG, Egger M, Pocock SJ, Gøtzsche PC, Vandenbroucke JP. The Strengthening the Reporting of Observational Studies in Epidemiology (STROBE) Statement: guidelines for reporting observational studies. nt J Surg. 2014 Dec;12(12):1495-9. doi:10.1016/j.ijsu.2014.07.013

10. Nyaga VN, Arbyn M, Aerts M. Metaprop: a Stata command to perform meta-analysis of binomial data. Arch Public Health. 2014 Nov 10;72(1):39. doi:10.1186/2049-3258-72-39

11. Lyons G, Sankaranarayanan R, Millar AB, Slama S. Scaling up cancer care in the WHO Eastern Mediterranean Region. Eastern Mediterranean Health Journal. 2018;24(1):104-10. PMID:29658627

12. Health systems strengthening in countries of the Eastern Mediterranean Region: challenges, priorities and options for future action. Cairo: World Health Organization, Regional Office for the Eastern Mediterranean; 2012.

13. Woods LM, Rachet B, O'Connell D, Lawrence G, Tracey E, Willmore A, et al. Large differences in patterns of breast cancer survival between Australia and England: a comparative study using cancer registry data. Int J Cancer. 2009 May;124(10):2391-9. doi:10.1002/ijc.24233

14. Zhu J, Chen JG, Chen YS, Zhang YH, Ding LL, Chen TY. Female breast cancer survival in Qidong, China, 1972-2011: a population-based study. BMC Cancer. 2014 May 6;14:318. doi:10.1186/1471-2407-14-318

15. Yeole BB, Kumar AVR, Kurkure A, Sunny L. Population-based survival from cancers of breast, cervix and ovary in women in Mumbai, India. Asian Pac J Cancer Prev. 2004;5(3):308-15. PMID:15373712

16. Breast cancer facts \& figures 2015-2016. Atlanta: American Cancer Society, Inc; 2015.

17. Allemani C, Sant M, Weir HK, Richardson LC, Baili P, Storm H, et al. Breast cancer survival in the US and Europe: A CONCORD high-resolution study. Int J Cancer. 2013 Mar 1;132(5):1170-81. doi:10.1002/ijc.27725

18. Sankaranarayanan R, Swaminathan R, Brenner H, Chen K, Chia KS, Chen JG, et al. Cancer survival in Africa, Asia, and Central America: a population-based study. Lancet Oncol. 2010 Feb;11(2):165-73. doi:10.1016/S1470-2045(09)70335-3

19. Khatib O, Aljurf M. Cancer prevention and control in the Eastern Mediterranean region: the need for a public health approach. Hematol Oncol Stem Cell Ther. 2008 Jan-Mar;1(1):44-52. PMID:20063528

20. Fredholm H, Eaker S, Frisell J, Holmberg L, Fredriksson I, Lindman H. Breast cancer in young women: poor survival despite intensive treatment. PLoS One. 2009 Nov 11;4(11):e7695. doi:10.1371/journal.pone.0007695

21. Brenner DR, Brockton NT, Kotsopoulos J, Cotterchio M, Boucher BA, Courneya KS, et al. Breast cancer survival among young women: a review of the role of modifiable lifestyle factors. Cancer Causes Control. 2016 Apr;27(4):459-72. doi:10.1007/s10552-0160726-5. 
22. Nematolahi S, Ayatollahi SMT. A comparison of breast cancer survival among young, middle-aged, and elderly patients in southern Iran using Cox and empirical Bayesian additive hazard models. Epidemiol Health. 2017 Oct 16;39:e2017043. doi:10.4178/epih. e2017043

23. Mousavi-Jarrrahi SH, Kasaeian A, Mansori K, Ranjbaran M, Khodadost M, Mosavi-Jarrahi A. Addressing the younger age at onset in breast cancer patients in Asia: an age-period-cohort analysis of fifty years of quality data from the international agency for research on cancer. ISRN Oncol. 2013 Sep 2;2013:429862. doi:10.1155/2013/429862

24. Abahssain H, Lalya I, Zahra EL M’Rabet F, Ismaili N, Razine R, Tazi MA, et al. Breast cancer in Moroccan young women: a retrospective study. BMC research notes. 2010;3(1):286.

25. Nemoto T, Vana J, Bedwani RN, Baker HW, McGregor FH, Murphy GP. Management and survival of female breast cancer: results of a national survey by the American College of Surgeons. Cancer. 1980;45(12):2917-24.

26. Jayasinghe UW, Taylor R, Boyages J. Is age at diagnosis an independent prognostic factor for survival following breast cancer? ANZ journal of surgery. 2005;75(9):762-7.

27. Oussama M, Kh MA. Guidelines for the early detection and screening of breast cancer. Cairo: World Health Organization Regional Office for the Eastern Mediterranean. 2006:24-6 (https://apps.who.int/iris/bitstream/handle/10665/119811/dsa701. pdf? sequence $=1$ \&isAllowed $=\mathrm{y}$, accessed 7 Octover 2019)

28. Coleman MP, Quaresma M, Berrino F, Lutz J-M, De Angelis R, Capocaccia R, et al. Cancer survival in five continents: a worldwide population-based study (CONCORD). Lancet Oncol. 2008 Aug;9(8):730-56. doi:10.1016/S1470-2045(08)70179-7

29. Kachuri L, De P, Ellison L, Semenciw R, Advisory Committee on Canadian Cancer Statistics. Cancer incidence, mortality and survival trends in Canada, 1970-2007. Chronic Dis Inj Can. 2013 Mar;33(2):69-80 PMID:23470172

30. Miller AB. Screening for breast cancer in the Eastern Mediterranean Region East Mediterr Health J. 2010 Oct;16(10):1022-4. PMID:21222416

31. Rahimzadeh M, Pourhoseingholi MA, Kavehie B. Survival rates for breast cancer in Iranian patients: a meta-analysis. Asian Pac J Cancer Prev. 2016;17(4):2223-7. doi:10.7314/apjcp.2016.17.4.2223

32. Arkoob K, Al-Nsour M, Al-Nemry O, Al-Hajawi B. Epidemiology of breast cancer in women in Jordan: patient characteristics and survival analysis. East Mediterr Health J. 2010 Oct;16(10):1032-8. PMID:21222418

33. Majid RA, Mohammed HA, Hassan HA, Abdulmahdi WA, Rashid RM, Hughson MD. A population-based study of Kurdish breast cancer in northern Iraq: hormone receptor and HER2 status. A comparison with Arabic women and United States SEER data. BMC Women's Health. 2012;12(1):16. doi:10.1186/1472-6874-12-16

34. Nissan A, Spira RM, Hamburger T, Badrriyah M, Prus D, Cohen T, et al. Clinical profile of breast cancer in Arab and Jewish women in the Jerusalem area. The Am J Surg. 2004 Jul;188(1):62-7. doi:10.1016/j.amjsurg.2003.11.039

35. Al Tamimi DM, Shawarby MA, Ahmed A, Hassan AK, AlOdaini AA. Protein expression profile and prevalence pattern of the molecular classes of breast cancer-a Saudi population based study. BMC Cancer. 2010 May 21;10:223. doi:10.1186/1471-2407-10-223

36. Sughayer MA, Al-Khawaja MM, Massarweh S, Al-Masri M. Prevalence of hormone receptors and HER2/neu in breast cancer cases in Jordan. Pathol Oncol Res. 2006;12(2):83-6. doi:PAOR.2006.12.2.0083

37. Hill TD, Khamis HJ, Tyczynski JE. Comparison of male and female breast cancer incidence trends, tumor characteristics, and survival. Ann Epidemiol. 2005;15(10):773-80. doi:10.1016/j.annepidem.2005.01.001

38. Levi F, Randimbison L, La Vecchia C. Breast cancer survival in relation to sex and age. Oncology. 1992;49(6):413-7.

39. Willsher PC, Leach IH, Ellis IO, Bourke JB, Blamey RW, Robertson JF. A comparison outcome of male breast cancer with female breast cancer. Am J Surg. 1997;173(3):185-8. doi:10.1016/s0002-9610(97)89592-x

40. Anderson WF, Althuis MD, Brinton LA, Devesa SS. Is male breast cancer similar or different than female breast cancer? Breast Cancer Res Treat. 2004;83(1):77-86.

41. Amirifard N, Sadeghi E. Breast cancer in men: a report from the Department of Radiation Oncology in Kermanshah Province, Iran. Asian Pac J Cancer Prev. 2016;17(5):2593-6. PMID:27268636

42. Scott-Conner C, Jochimsen P, Menck H, Winchester D. An analysis of male and female breast cancer treatment and survival among demographically identical pairs of patients. Surgery. 1999;126(4):775-81. PMID:10520928

43. Bezwoda WR, Hesdorffer C, Dansey R, de Moor N, Derman DP, Browde S, et al. Breast cancer in men. Clinical features, hormone receptor status, and response to therapy. Cancer. 1987;60(6):1337-40. doi:10.1002/1097-0142(19870915)6o:6<1337::aid-cncr2820600629>3.0.co;2-c

44. Wagner JL, Thomas CR, Koh WJ, Rudolph RH. Carcinoma of the male breast: update 1994. Med Pediatr Oncol. 1995;24(2):123-32. doi:10.1002/mpo.2950240213

45. Abdollahi A, Zadeh HS, Akbari M, Tahmasbi S, Talei A, Hassanzadeh J. Investigation of prognostic factors and survival without recurrence in patients with breast cancer. Adv Biomed Res. 2017 Apr 17;6:42. doi:10.4103/2277-9175.204595

46. Al-Moundhri M, Al-Bahrani B, Pervez I, Ganguly S, Nirmala V, Al-Madhani A, et al. The outcome of treatment of breast cancer in a developing country-Oman. Breast. 2004;13(2):139-45. doi:10.1016/j.breast.2003.10.001.

47. Abdelkrim SB, Fathallah K, Rouatbi R, Ayachi M, Hmissa S, Mokni M. OM. Breast cancer in very young women aged 25 year-old or below in the center of Tunisia and Review of the Literature. Pathol Oncol Res. 2015;21(3):553-61. doi:10.1007/s12253-015-9944-5 
48. Aghili M, Lashkari M, Farrokhpey AH, Izadi S. Triple-negative breast cancer survival in Iranian patients. Acta Med Iran. 2013 Sep 9;51(8):560-6. PMID:24026994

49. Ahmed SB, Aloulou S, Bibi M, Landolsi A, Nouira M, Fatma LB, et al. Pronostic du cancer du sein chez les femmes tunisiennes: analyse d'une série hospitalière de 729 patientes [Breast cancer prognosis in Tunisian women: analysis of a hospital series of 729 patients]. Santé Publique. 2002;14(3):231-41. PMID:12564048

50. Akbari ME, Mozaffar M, Heidari A, Zirakzadeh H, Akbari A, Akbari M, et al. Recurrence and survival effect in breast conserving surgery: what are the predictive and/or prognostic factors? Iran J Cancer Prev. 2011;4(2):49-54.

51. Akbari ME, Khayamzadeh M, Khoshnevis S, Nafisi N, Akbari A. Five and ten years survival in breast cancer patients mastectomies vs. breast conserving surgeries personal experience. Iran J Cancer Prev. 2012;1(2):53-6.

52. Akbari M, Mirzaei H, Soori H. 5 year survival of breast cancer in Shohada-e-Tajrish and Jorjani hospitals. Hakim Resh J. 2006;9(2):39-44.

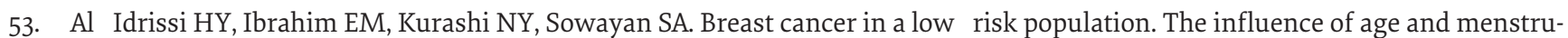
al status on disease pattern and survival in Saudi Arabia. Int J Cancer. 1992;52(1):48-51. doi:10.1002/ijc.2910520111

54. Alaoui SK, Debbagh A, Sbitti Y, Errihani H, Ichou M. [Male breast cancer in Morocco: Epidemiology and prognostic factors. A report of 140 cases]. Gynecol Obstet Fertil. 2016 Nov;44(11):636-40 (in French). doi: 10.1016/j.gyobfe.2016.08.009

55. Aziz Z, Iqbal J, Akram M. Predictive and prognostic factors associated with survival outcomes in patients with stage I-III breast cancer: A report from a developing country. Asia®Pacific J Clin Oncol. 2008;4(2):81-90. doi:10.1111/j.1743-7563.2008.00152.x

56. Babaie GR, Feyzi A, Keshavarz M. The effect of various therapeutic and surgical methods on the survival of patients with breast cancer. Daneshvar Medicine. 2005;13(59):19-28.

57. Baghestani A, Moghaddam S, Majd H, Akbari M, Nafissi N, Gohari K. Survival analysis of patients with breast cancer using Weibull Parametric Model. Asian Pac J Cancer Prev. 2015;16(18):8567-71. PMID:26745118

58. Bakkach J, Mansouri M, Derkaoui T, Loudiyi A, Fihri M, Hassani S, et al. Clinicopathologic and prognostic features of breast cancer in young women: a series from North of Morocco. BMC Womens Health. 2017 Nov 9;17(1):106. doi:10.1186/s12905-017-0456-1

59. Ben Gobrane H, Fakhfakh R, Rahal K, Ben Ayed F, Maalej M, Ben Abdallah M, et al. [Breast cancer prognosis in Salah Azaiez Institute of Cancer, Tunis] East Mediterr Health J. 2007;13(2):309-18 (in French). PMID:17684853

6o. Bhatti A, Khan AI, Siddiqui N, Muzaffar N, Syed AA, Shah MA, et al. Outcomes of triple-negative versus non-triple-negative breast cancers managed with breast-conserving therapy. Asian Pac J Cancer Prev. 2014;15(6):2577-81. doi:10.7314/apjcp.2014.15.6.2577

61. Bhatti ABH, Jamshed A, Shah MA, Khan A. Breast conservative therapy in Pakistani women: Prognostic factors for locoregional recurrence and overall survival. J Cancer Res Ther. 2015 Apr-Jun;11(2):300-4. doi:10.4103/0973-1482.140828

62. Bouzid N, Lahmar R, Tebra S, Bouaouina N. [Breast cancer in woman younger than 35 years in Tunisia: retrospective study about 124 cases]. Gynecol Obstet Fertil. 2013 Jun;41(6):356-60 (in French). doi:10.1016/j.gyobfe.2013.05.002

63. Derkaoui T, Bakkach J, Mansouri M, Loudiyi A, Fihri M, Alaoui FZ, et al. Triple negative breast cancer in North of Morocco: clinicopathologic and prognostic features. BMC Women's Health. 2016;16(1):68. doi:10.1186/s12905-016-0346-y

64. Dhiab B, Bouzid T, Gamoudi A, Hassouna B, Khomsi F, Boussen H, et al. [Male breast cancer: about 123 cases collected at the Institute Salah-Azaiz of Tunis from 1979 to 1999]. Bull Cancer. 2005;92(3):281-5 (in French). PMID:15820923

65. El Amine EO, Nasri M, Thabet S, Ben HJ, Goucha A, Rahal K, et al. Primary breast sarcomas: About 30 cases treated at Salah-Azaiez institute in Tunisia. Cancer Radiother. 2017 Feb;21(1):45-50 (in French). doi:10.1016/j.canrad.2016.09.011

66. El Mistiri M, Salati M, Marcheselli L, Attia A, Habil S, Alhomri F, et al. Cancer incidence, mortality, and survival in Eastern Libya: updated report from the Benghazi Cancer Registry. Ann Epidemiol. 2015;25(8):564-8. https://doi.org/10.1016/j.annepidem.2015.03.012

67. El-Baradie M, Salama A, Khorshid O, Ismail H, Attia G, Bahnassy AA. Egyptian male breast carcinoma: patients' hormonal profile, management and outcome. Chinese-German J Clin Oncol. 2012;11(2):89-98.

68. El-Beshbeshi W, Abo-Elnaga EM. Male breast cancer: 10-year experience at mansoura university hospital in Egypt. Cancer Biol Med. 2012 Mar;9(1):23-8. doi:10.3969/j.issn.2095-3941.2012.01.004

69. El-Habbash MM, Alwindi AA. Male breast cancer in Tripoli, Libya. Saudi Med J. 2009;30(8):1060-2. PMID:19668888

70. Elshafiey MM, Zeeneldin AA, Elsebai HI, Moneer M, Mohamed DB, Gouda I, et al. Epidemiology and management of breast carcinoma in Egyptian males: Experience of a single Cancer Institute. J Egypt Natl Canc Inst. 2011 Sep;23(3):115-22. doi:10.1016/j. jnci.2011.10.001

71. Fakhro A. Breast cancer: patient characteristics and survival analysis at Salmaniya medical complex, Bahrain. East Mediter Health J. 1999;5(3):430-9. https://apps.who.int/iris/handle/10665/118724

72. Fallahzadeh H, Momayyezi M, Akhundzardeini R, Zarezardeini S. Five year survival of women with breast cancer in Yazd. Asian Pac J Cancer Prev. 2014;15(16):6597-601. doi:10.7314/apjcp.2014.15.16.6597

73. Faradmal J, Roshanaei G, Mafi M, Sadighi-Pashaki A, Karami M. Application of censored quantile regression to determine overall survival related factors in breast cancer. J Res Health Sci. 2016;16(1):36-40. PMID:27061995 
74. Fardmal J, Mafi M, Sadighi-Pashaki A, Karami M, Roshanaei G. Factors affecting survival in breast cancer patients referred to the Darol Aitam-e Mahdieh Center. J Zanjan University Med Sci Health Serv. 2014;22(93):105-15.

75. Fayaz MS, El-Sherify MS, El-Basmy A, Zlouf SA, Nazmy N, George T, et al. Clinicopathological features and prognosis of triple negative breast cancer in Kuwait: A comparative/perspective analysis. Rep Pract Oncol Radiother. 2013 Sep 26;19(3):173-81. doi:10.1016/j.rpor.2013.08.007

76. Fazeli Z, Najafian ZM, Eshrati B, Almasi Ha. Five-year evaluation of epidemiological, geographical distribution and survival analysis of breast cancer in Markazi Province, Arak Med Univ J. 2014;16(80):72-9.

77. Haghighat S. Survival rate and its correlated factors in breast cancer patients referred to Breast Cancer Research Center. Iran J Breast Dis. 2014;6(3):28-36.

78. Hajihosseini M, Faradmal J, Sadighi-Pashaki A. Survival analysis of breast cancer patients after surgery with an intermediate event: application of illness-death model. Iran J Public Health. 2015;44(12):1677-84. PMID:26811819

79. Hamadeh RR, Abulfatih NM, Fekri MA, Al-Mehza HE. Epidemiology of breast cancer among Bahraini women: data from the Bahrain Cancer Registry. Sultan Qaboos Univ Med J. 2014;14(2):e176-82. PMID:24790739

80. Hamdan N, Ravichandran K, Dyab A. Breast cancer survival in Riyadh, Saudi Arabia, 1994\1996. IARC Sci Publ. 2011;(162):179-81. PMID:21675422

81. Heydari ST, Mehrabani D, Tabei S, Azarpira N, Vakili M. Survival of breast cancer in southern Iran. Iran J Cancer Prev. 2009;2(1):51-4.

82. Hoseini M, Bahrampour A, Mirzaee M. Comparison of Weibull and Lognormal cure models with Cox in the survival analysis of breast cancer patients in Rafsanjan. J Res Health Sci. 2017 Feb 16;17(1):e00369. PMID:28413171

83. Ibrahim EM, Al-Mulhim FA, Al-Amri A, Al-Muhanna FA, Ezzat AA, Stuart RK, et al. Breast cancer in the eastern province of Saudi Arabia. Med Oncol. 1998 Dec;15(4):241-7. PMID:9951687

84. Iqbal J, Bano K, Saeed A, Akram M, Aziz Z. Survival of women with locally advanced breast cancer at a teaching hospital in Lahore. J Pak Med Assoc. 2010;60(9):721. PMID:21381576

85. Jamy O, Rafiq A, Laghari A, Chawla T. Male breast cancer: a 24 year experience of a tertiary care hospital in Pakistan. Asian Pac J Cancer Prev. 2015;16(4):1559-63. doi:10.7314/apjcp.2015.16.4.1559

86. Kallel M, Elloumi F, Khabir A, Ghorbal L, Chaabouni S, Amouri H, et al. Breast cancer in young women in southern Tunisia: Anatomical study and clinical prognostic factors: About a series of 83 patients. Rep Pract Oncol Radiother. 2015 MayJun;20(3):155-60. doi:10.1016/j.rpor.2015.01.007

87. Karimi A, Delpisheh A, Sayehmiri K. Application of accelerated failure time models for breast cancer patients' survival in Kurdistan Province of Iran. J Cancer Res Ther. 2016 Jul-Sep;12(3):1184-8. doi:10.4103/0973-1482.168966

88. Khanfir A, Frikha M, Kallel F, Meziou M, Trabelsi K, Boudawara T, et al. [Breast cancer in young women in the south of Tunisia]. Cancer Radiother. 2006;10(8):565-71 (in French). doi:10.1016/j.canrad.2006.09.115

89. Kumar S, Shaikh A, Rashid Y, Masood N, Mohammed A, Malik U, et al. Presenting features, treatment patterns and outcomes of patients with breast cancer in Pakistan: Experience at a university hospital. Indian J Cancer. 2016 Apr-Jun;53(2):230-4. doi:10.4103/0019-509X.197728

90. Kumar S, Burney IA, Al-Ajmi A, Al-Moundhri MS. Changing trends of breast cancer survival in sultanate of Oman. J Oncol. 2011:316243. doi:10.1155/2011/316243

91. Mechita NB, Tazi MA, Er-Raki A, Mrabet M, Saadi A, Benjaafar N, et al. [Survival rate for breast cancer in Rabat (Morocco) 20052008]. Pan Afr Med J. 2016 Nov 11;25:144 (in French). doi:10.11604/pamj.2016.25.144.10402

92. Moghadami Fard Z, Gohari M. Survival analysis of patients with breast cancer using the Aalen's additive hazard model. J North Khorasan Univ Med Sci. 2012;3(5):171-9.

93. El Mongy M, El Hossieny H, Haggag F, Fathy R. Clinico-pathological study and treatment results of 1009 operable breast cancer cases: Experience of NCI Cairo University, Egypt. Chinese-German J Clin Oncol. 2010;9(7):409-15.

94. Mosavi-Naeini S, Mofid B, Mohebbi H, Mehmannavaz M, Khoshini S. [Comparison of regional recurrence, metastasis and survival rate between two surgical methods in the treatment of breast cancer stage I and II]. Kowsar Med J. 2009;14(2):89-94 (in Farsi).

95. Mousavi SM, Mohagheghi MA, Mousavi-Jerrahi A, Nahvijou A, Seddighi Z. Outcome of breast cancer in Iran: a study of Tehran Cancer Registry data. Asian Pac J Cancer Prev. 2008 Apr-Jun;9(2):275-8. PMID:18712973

96. Movahedi M, Haghighat S, Khayamzadeh M, Moradi A, Ghanbari-Motlagh A, Mirzaei H, et al. Survival rate of breast cancer based on geographical variation in iran, a national study. Iran Red Cresc Med J. 2012;14(12):798.

97. Payandeh M, Sadeghi M, Sadeghi E, Aeinfar M. Clinicopathology figures and long-term effects of tamoxifen plus radiation on survival of women with invasive ductal carcinoma and triple negative breast cancer. Asian Pac J Cancer Prev. 2015;16(12):4863-7. doi:10.7314/apjcp.2015.16.12.4863

98. Shahraki HR, Salehi A, Zare N. Survival prognostic factors of male breast cancer in Southern Iran: a LASSO-Cox regression approach. Asian Pac J Cancer Prev. 2015;16(15):6773-7. doi:10.7314/apjcp.2015.16.15.6773

99. Rais G, Raissouni S, Aitelhaj M, Rais F, Naciri S, Khoyaali S, et al. Triple negative breast cancer in Moroccan women: clinico- 
pathological and therapeutic study at the National Institute of Oncology. BMC Women's Health. 2012;12(1):35. doi:10.1186/14726874-12-35

100. Rajaeefard A, Baneshi M, Talei A, Mehrabani D. Survival models in breast cancer patients. Iran Red Cresc Med J. 2009;11(3):295-300.

101. Rampisheh Z, Motamed N, Amiri M, Ostovar A, Azarnoush A, Bahramian F, et al. Breast cancer survival rate according to data of cancer registry and death registry systems in Bushehr province, 2001-2013. Iran South Med J. 2015;18(4):729-37.

102. Ravichandran K, Hamdan NA, Dyab A. Population based survival of female breast cancer cases in Riyadh Region, Saudi Arabia. Asian Pac J Cancer Prev. 2005;6(1):72-6. PMID:15780037

103. Rezaianzadeh A, Peacock J, Reidpath D, Talei A, Hosseini SV, Mehrabani D. Survival analysis of 1148 women diagnosed with breast cancer in Southern Iran. BMC Cancer. 2009 Jun 5;9:168. doi:10.1186/1471-2407-9-168.

104. Salehi A, Zeraati H, Mohammad K, Mahmoudi M, Talei A, Ghaderi A, et al. Survival of male breast cancer in Fars, South of Iran. Iran Red Cresc Med J. 2011;13(2):99.

105. Sedehi M, Amani F, Momeni DF. Analysis of survival data of patient with breast cancer using artificial neural network and cox regression models. J Zabol Univ Med Sci Health Serv. 2014;5(4):24-32.

106. Shawky H, Younes SG, Sadaka E, Elgohary SE-D, Sallam FA. Male breast cancer-a 10-year review of 29 cases at Tanta University Hospital. Life Sci J. 2013;10(1)

107. Soliman AA, Denewer AT, El-Sadda W, Abdel-Aty AH, Refky B. A retrospective analysis of survival and prognostic factors of male breast cancer from a single center. BMC Cancer. 2014 Mar 28;14:227. doi:10.1186/1471-2407-14-227

108. Vahdaninia M, Harirchi AM, Montazeri A. [Five years survival rate in women with breast cancer referring to Imam Khomeini Hospital: a prospective study]. Payesh Health Monitor. 2003;2(2):141-8 (in Farsi).

109. IVostakolaei FA, Broeders MJ, Rostami N, Van Dijck JA, Feuth T, Kiemeney LA, et al. Age at diagnosis and breast cancer survival in Iran. Int J Breast Cancer. 2012;2012:517976. doi:10.1155/2012/517976

110. Yaghmaei S, Bani Hashemi G, Ghorbani R. Survival rate following treatment of primary breast cancer in Semnan, Iran (19912002). Koomesh. 2008;9(2):111-6.

111. Znati K, Bennis S, Abbass F, Akasbi Y, Chbani L, Elfatemi H, et al. Breast cancer in young patient in Morocco. Gynecol Obstet Fertil. 2014 Mar;42(3):149-54. doi:10.1016/j.gyobfe.2011.08.014

112. Zare N, Doostfatemeh M, Rezaianzadeh A. Modeling of breast cancer prognostic factors using a parametric log-logistic model in Fars province, Southern Iran. Asian Pac J Cancer Prev. 2012;13(4):1533-7. doi:10.7314/APJCP.2012.13.4.1533

113. Ziaei JE, Sanaat Z, Asvadi I, Dastgiri S, Pourzand A, Vaez J. Survival analysis of breast cancer patients in northwest Iran. Asian Pac J Cancer Prev. 2013;14(1):39-42. doi:10.7314/APJCP.2013.14.1.39 